Ciência e Natura, v. 37 Part 2 jun. 2015, p. 35-44

\title{
Efficacy of type and value of auditing opinion on time revelation of information
}

\author{
Ramin Ehsani Tabar ${ }^{1}$, Masood Taheri Nia² \\ 1-Mastert of Accounting, Islamic Azad University, Khoram Abad Iran \\ 2-Assistannc Professor, Department of Management, Lorestan University, Khoram Abad Iran
}

\begin{abstract}
The main goal of this research is surveying efficacy of type and value of variation of Auditing opinion on time revealing of accepted companies of Tehran commercial papers bourse Statistics society of this research is accepted companies in the Tehran commercial papers since (2009 to 2013) years, that content of sample after screen manner correspond 101companies. In this research have been used from boarding and incorporating data with fixed effects. Outcomes of analysis by some variant regression in the assurance level $95 \%$ shows that variation of Auditing opinion type and variation value of Auditing opinion type cause increase of on time revelation of companies financial reports.
\end{abstract}

Keywords: variation of auditing opinion, on time revelation, quality of revelation, Tehran commercial papers burse.

\section{Introduction}

Investors and trusters are two main group of users of organism outside of financial information.

Preparing and obtaining of relevant and on time information for these two group are one of the main duties of management and accounting systems. Being in time means that information must be announced in the shortest time and the fastest possible shape, and be available users. Whatever time interval and date of announcement trade units information become shorter, it will increase advantageous of product from trade units financial information.

There are several studies in accounting literature, that it shows being on time revelation cause increase of informed quality and decrease if informational asymmetry. (Noravesh and Hoseiny, "2009").

Beside role and nature of auditing is being discussed relation with uncertainly and dubieties on quality of reported accounting information.

Accounting is prepared in first line of investigation, opinion about favorable and 
finally authenticate to management,s claim insertion in the financial bill.

Auditing is as a social organism, for help to super intendancy and control of managers, $\mathrm{s}$ treatment and as super intendancy tool of governments.

Whatever the society anticipate from accounting career, presentation of accounting reports, that cause increase capability of reliance and being on time exposed accounting information. It is additional value that just accounting career can increase it to the companies financial information.

So if accounting be a super intendancy tool that undertakes foresaid several roles, with suppose fixed the other qualification, accounting report must about financial bills long range as a super intendancy mechanism cause improvement of quality of revelation information by increase being on time accounting information revelation.

Therefore in this research have been surveyed "relation of variation of type and value of variation of auditing."

Opinion with being on time revelation.

Theory frame and history of research.

Investors and trusters are two main group of users of organism outside of financial information. Preparing and obtaining of relevant information for these two group are one of the main duties of management and accounting systems. Companies acquit this duty by revelation of information in frame financial reporting. Financial bills constitute a main section of financial reporting. In fact effective revelation of information to the organism outside people with on time and authentic manner, is main role of financial reporting.

Being on time is one of the most important properties modality of financial information. being on time means information must be announced and be available users into the shortest time and fastest possible form.
Whatever time interval and announcement date of trade units information be shorter, advantage owners from trade units financial information increase. There are several studies in the accounting literacy quality of information and it decrease information asymmetry.(Noravesh and Hoseiny, "2009").

Whatever society anticipate from auditing career, is representation of auditing reports cause increase capability of recumbence and being on time exposed accounting information. It is an additional value that it,s just auditing career can it increase to the companies financial information. So if auditing is a super intendancy tool that undertake foresaid several roles, with to suppose fixed the other conditions, Auditing report must cause improvement of financial information revelation quality about financial bills in long rang as a super intendancy mechanism, by increase being time of accounting information revelation. (yasaee, "2016").

The kinds of Auditing opinion according with Iran auditing standards include following:

- Accepted opinion include following

- provisional opinion according

- inexistence opinion accounting

- and rejected opinion.

In this research effectiveness of dependent variables, independent variables, and also control variables and relation of those in respective statics society have been surveyed with models of researches,s Colinan and his cooperators(2012).

Rib and jac (2013) surveyed in their research relation of between education, working experiment and management corps communications network with being of revelation.

Conclusion of their findings signify between education, and working experiment and management corps communication network 
with being on time of revelation there is a semantic direct relation.

Colinan and his cooperators (2012)wrap up in a research with sub title effectiveness of Auditing opinion improvement on being on time of revelation, that Auditing opinion improvement and its value have positive and direct effect on being on time financial reports revelation.

Conclusions of their findings show variation of Auditing opinion to the accepted as a good news has the most effect and variation of Auditing opinion to the rejected as a bad news has the most effect on companies revelation.

Menon and Williams (2010) in their research surveyed bazaar reaction and investors to the kinds of Auditor report.

Conclusion of their findings show provisional opinion has been included as a bad news so companies expose their financial reports belated according to signaling theory.

Also these conclusions show reaction of investors to the provisional report cause it decreases stock's price of these companies.

Conclusions of watts and plafond's (2008) research show companies with high growth chances lean to present quality of financial reporting and lower revelation overhand, when companies are finishing their investment projects and potential ability of their future growth is lower, it decreases information asymmetry and consequence quality of financial reporting increase.

Bick and Brown (2006) discuss this problem that companies with govern of effective cooperative, do better informant accounting revelation this makes to decrease information asymmetry.

The problem of company govern innately engender from problem of information asymmetry and agency. Problem of revenue opposition makes to impress company Market measuring and it,s operation.
Alsaeed (2006) wraps up in his research that companies with higher revenue of stockholder salary lean revelation of more information comparatively companies with lower revenue.

Le and woo (2004) surveyed in a research effective of type of Auditing report and also type of improvement of Auditing report, on market reaction and investors. Conclusions of these studies show that Auditor opinion improvement included as a news and companies with of Auditing opinion improvement from provisional to accepted have the most positive effect and versus companies with Auditing opinion improvement to rejected have the most negative effect on market reaction and investors.

Lang and Landholm(2003) claimed that revelation of companies govern procedures makes to decrease informational asymmetry and stockers can super intendance effectively on management of company.

How and his cooperators (2002) surveyed in a research type relation of effective of Auditing report type and type of news on schedules of revelation. conclusions of their findings show that both of factors, type of news and type of Auditing report effect on schedules of companies revelation, as companies with the good news (increase of profit toward last year) and Auditing provisional report toward companies with the bad news (decrease of profit toward last year) and accepted report of profit and their financial reports expose with more delay.

Setayesh and kazem Nejad (2012) in a research with subtitle "recognition and specification of effective factors on quality of revelation of accepted companies information in Tehran commercial paper" wrapt up that quality of revelation has semantic and direct relationship with antecedent, cash, profitability and size of accounting institution and also it has semantic and converse relationship with financial fulcrum and family possession of accepted companies in Tehran commercial paper burse. 
Nonetheless they didn,t find any witness indicative existence of semantic relationship between quality of revelation with company size and management corps conformation.

Etemadi and his cooperators (2011) surveyed valuable content of obliging revelation.

Conclusion of their research show that exposed in companies reports include informational content about future profits and investors use from these exposed information in their decision making.

Vahdati (2011) surveyed in a research effective factors on selection of auditing opinion and value of efficacity of these factors on selection of opinion his research findings show that there is relation between auditor shift from the auditing organization to the auditing private institution, auditor shift from a auditing private institution to the other auditing private institution, management operation and workload size with selection of opinion, but there is not semantic relation between change of workload possession with selection of opinion conclusion of fore researches like Colinan and his cooperators (2012) show that Auditing opinion type as an efficient super intendancy tool and mechanism makes to increase quality of information and it,s pursuit makes to increase being on time financial reports and revelation of companies.

\section{Research Method}

This investigation is an application research. Its models investigation is a kind of back event (by past information).

To collect information is used library method and information of commercial paper bourse organization site, new souvenir software, and processing contraption. In this investigation is used combinational data method as for kind of data and available statistical analysis methods. Theory information and past research findings and research necessity data are collected exactly from secondary sources. To collect information about subject literature and research history and elicit formulas of research variables is used library method. Statistical data Relation with research hypothesis have been elicit with organizational documents method from companies facial bills and as for research hypothesizes variants data have been computed from get information.

Therefore, necessity data for this investigation will have been collected by computerly information banks and reference to the library of bourse organization and commercial paper and by new souvenir software and reference to the web site www.rdis.ir belong bourse organization and commercial paper (investigation management, development and Islamic studies). Also companies financial bills include balance sheet, cash modes current bill and notes with financial bills have been used as research tool in the end of every financial year (Esfand mounth 29).

In this research statistical sample are selected with systematic deletion method between accepted companies in Tehran commercial paper bourse and to 101 companies and

In period 2009 to 2013.

\section{Research hypotheses:}

First hypothesis: there are relation between variations of Auditing opinion type and being on time revelation.

Second hypothesis: there are relation between variations value of Auditing opinion type and being on time revelation. 
Independent variable

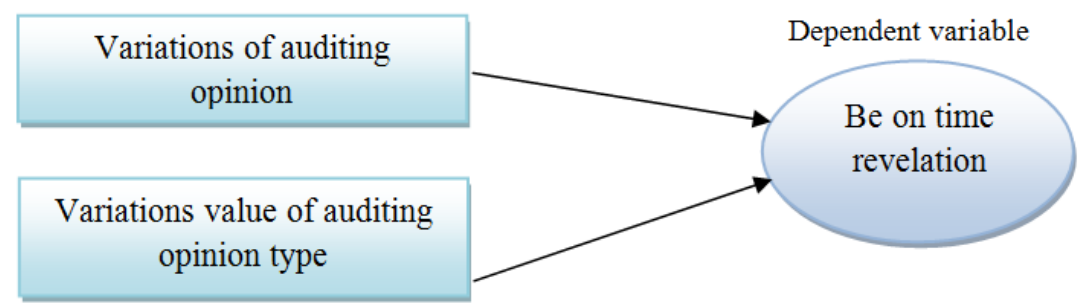

\section{Dependent variant}

DEL=index of being on time revelation is that earn from difference of data of company financial period end with presentation data and financial bills report.

\section{In dependent variable}

DIMP = variation of Auditing opinion type is figural variable, while Auditing opinion is changed to word past period is imprinted number 1 , otherwise it is imprinted number 0 .

\section{Control variables:}

$\mathrm{UE}=$ changes percent in pure profit toward past period.

$\mathrm{AS}=$ auditor shift that is figurative variable while company auditor is shifted toward past period, is imprinted number1, otherwise it is imprinted number0

$\mathrm{DUAL}=$ manager dual that is figurative variable, while he /she is manager of management crop member also, it is imprinted number1, otherwise it is imprinted number0.

$\mathrm{LEV}=$ financial fulcrum that is earned from relation of debits book value to book value of all finances in the end of year.

The first hypothesis test model:

Sightly model for the first hypothesis test that is obtained researches of Colinan and his cooperators (2012) include: our good in this model is surveying positive change (improvement) in the Auditing opinion on being on time revelation.

$$
\begin{aligned}
\text { DEL }_{\text {it }}=\beta_{0}+\beta_{1} \mathrm{DIMP}_{\mathrm{i}, t}+\beta_{2} \mathrm{UE}_{\mathrm{i}, t}+\beta_{3} \mathrm{LEV}_{\mathrm{i}, \mathrm{t}}+\beta_{4} \mathrm{AS}_{\mathrm{i}, \mathrm{t}} \\
+\beta_{5} \mathrm{DUAL}_{\mathrm{i},}+\varepsilon_{\mathrm{i}, \mathrm{t}}
\end{aligned}
$$

\section{Independent variant:}

OPNCHG=variation value of type Auditing opinion.

In this research type Auditing professional opinion is coded at the number of one to five include:

- standard accepted of the number five (5)

- accepted with explanatory clause of the number four(4)

- provisional of the number three(3)

- provisional with explanatory clause of the number two(2)

- $\quad$ rejected of the number one(1)

To survey variation value of Auditing opinion type is used following index:

$$
\mathrm{OPNCHG}_{\mathrm{t}}=\mathrm{AUDOPN}_{\mathrm{t}-1}-\mathrm{AUDOPN}_{\mathrm{t}}
$$

That the index earn difference of corresponding number to Auditing opinion type in past year with corresponding number to Auditing opinion in current year, that is always a number between -4 to +4

The second hypothesis test model:

Also sightly model for the second hypothesis that is obtained researches of Colinan and cooperators (2012)

Include: 
our goal in this model is surveying variation value (whether positive or negative ) in Auditing opinion type on being on time revelation.

$$
\begin{aligned}
\text { DEL }_{i t}= & \beta_{0}+\beta_{1} \mathrm{OPNCHG}_{\mathrm{i}, \mathrm{t}}+\beta_{2} \mathrm{UEi}_{, \mathrm{t}}+\beta_{3} \mathrm{LEV}_{\mathrm{i}, \mathrm{t}} \\
& +\beta_{4} \mathrm{AS}_{\mathrm{i}, \mathrm{t}}+\beta_{5} \mathrm{DUAL}_{\mathrm{i},}+\boldsymbol{\varepsilon}_{\mathrm{i}, \mathrm{t}}
\end{aligned}
$$

Data descriptive statistics:

In the table(1), show descriptive statistic of research variants in surveyed period. research variants descriptive statistics have been presented, include average, mean, standard deviation, minimum and maximum, that have been admeasured by sample companies data.

Table 1, descriptive Statistics of research variables:

\begin{tabular}{|c|c|c|c|c|c|c|}
\hline \multicolumn{2}{|c|}{ Explanation of variables } & average & Mean & deviation & Minimum & maximum \\
\hline DEL & Being on time revelation & 68 & 63 & 23.56 & 35 & 110 \\
\hline DIMP & $\begin{array}{c}\text { Variation of Auditing opinion } \\
\text { type }\end{array}$ & 0.309 & 0 & 1.564 & 0 & 1 \\
\hline OPNCHG & $\begin{array}{c}\text { Value variation of Auditing } \\
\text { opinion type }\end{array}$ & 2.78 & 0 & 1.675 & 0 & 4 \\
\hline UE & $\begin{array}{c}\text { Changes percent in pure } \\
\text { profit toward past period }\end{array}$ & 0.46783 & 0.3785 & 1.6732 & $0.2264-$ & 0.758945 \\
\hline AS & Shift Auditor & 0.509 & 0 & 1.564 & 0 & 1 \\
\hline DUAL & Manager dual & 0.267 & 0 & 1.564 & 0 & 1 \\
\hline LEV & Financial fulcrum & 0.656695 & 0.654578 & 0.096477 & 0.491998 & 0.822768 \\
\hline
\end{tabular}

Findings surveying and interpretation research con collusions:

The first hypothesis test

There is relation between variations of Auditor's opinion type and being on time revelation.

\section{Conclusion of test:}

According with table1, variable variation of Auditing opinion type are meaningful in accuracy level $95 \%$ in research regression model and research hypothesis is accepted, based that there is relation between variation of Auditing opinion type and being on time revelation.

Beside we can claim, as for modulus of variable positive in regression type makes to increase being time companies financial reports revelation. These conclusions correspond to findings of Comren, Prinsip and Trambeta (2008), Goor, Pop and sighn(2001), Elder, jhao (2001), Farezana and Rashideh (2006), ming (2007), Frasis (1999), Azibi and Raji (2008) and chen (2005).

In analysis of upon conclusions we can say that control auditing mechanism that final product of the auditing report is considered relation to doubts and uncertainty on quality of reported auditing information good auditing report makes to increase information credit and quality of financial information. Whereas being on time is one of the most important property quality of information, therefore it is supposed to correlate directly that positive changes in type auditor opinion and being on time financial reports, as for positive relation to variation of Auditing opinion type with being on time accepted companies revelation in Tehran commercial paper bourse actives of fund Market, determiners, financial analyzer and defacto and potential investors in commercial paper bourse they can when analysis of investment schemes in financial and commercial paper, 
they decide optimumly that cause adventure minimum and the most revenue, as for positive variations of type Auditing opinion type that effect positively on being time financial report and companies revelation. 
Table 2, conclusion of practice of regression equation.

\begin{tabular}{|c|c|c|c|c|c|}
\hline \multicolumn{6}{|c|}{$D E L_{i t}=\beta_{0}+\beta_{1} D I M P_{i, t}+\beta_{2} U E_{i, t}+\beta_{3} L E V_{i, t}+\beta_{4} A S_{i, t}+\beta_{5} D U A L_{i,}+\varepsilon_{i,}$} \\
\hline \multicolumn{2}{|r|}{ Variable name } & Modulus & amount & Statistic T & $\begin{array}{c}\text { meaningful } \\
\text { level }\end{array}$ \\
\hline \multicolumn{2}{|r|}{ fixed number } & $\beta_{0}$ & 1.522 & 2.873 & 0.004 \\
\hline \multirow{2}{*}{$\begin{array}{c}\text { DIMP } \\
\text { UE }\end{array}$} & $\begin{array}{c}\text { Variations value of Auditing opinion } \\
\text { type }\end{array}$ & $\beta_{1}$ & 3.324 & 2.109 & 0.041 \\
\hline & $\begin{array}{l}\text { Changes percent in pure profit toward } \\
\text { past period }\end{array}$ & $\beta_{2}$ & 2.467 & 3.838 & 0.000 \\
\hline \multirow{2}{*}{$\begin{array}{c}\text { LEV } \\
\text { AS }\end{array}$} & Financial fulcrum & $\beta_{3}$ & -2.311 & -2.987 & 0.0031 \\
\hline & Shift auditor & $\beta_{4}$ & -1.241 & -2.347 & 0.034 \\
\hline \multirow[t]{2}{*}{ DUAL } & Manager dual & $\beta_{5}$ & -0.943 & -0.745 & 0.651 \\
\hline & Determination modulus & 0.521 & \multicolumn{2}{|c|}{ Statistic F } & 11.278 \\
\hline \multirow{2}{*}{\multicolumn{2}{|c|}{ Adapted determination modulus }} & \multirow{2}{*}{0.476} & \multicolumn{2}{|c|}{$\begin{array}{l}\text { Meaningfully(p- } \\
\text { value })\end{array}$} & 0.111 \\
\hline & & & \multicolumn{2}{|c|}{$\begin{array}{l}\text { Durbin Watson } \\
\text { statistic }\end{array}$} & 1.811 \\
\hline
\end{tabular}

\section{The second hypothesis test:}

"There is relation between variation, value of Auditor's opinion type and being on time revelation ".

\section{Conclusion of test:}

According to table 2, variable of variation value of Auditing opinion type is meaningful in confidence level $95 \%$ in research regression model, and $\mathrm{H}_{1} 1$ hypothesis is accepted based that there is relation between variation value of Auditing opinion type and being on time revelation. otherwise we can claim that variable of variation value of Auditing opinion type makes to increase being on time revelation of companies financial reports, as for negative modulus of this variable in regression model. These conclusions correspond to findings of Comren, prinsip and Trambeta (2008), goor, popand sighn (2001), Elder and jhao (2001), Farozana and Rashideh (2006), ming (2007),Fransis (1999), azibi and Raji (2008) and chen (2005).

\begin{tabular}{|c|c|c|c|c|c|}
\hline \multicolumn{6}{|c|}{$D E L_{i t}=\beta_{0}+\beta_{1} D I M P_{i, t}+\beta_{2} U E_{i, t}+\beta_{3} L E V_{i, t}+\beta_{4} A S_{i, t}+\beta_{5} D U A L_{i,}+\varepsilon_{i,}$} \\
\hline \multicolumn{2}{|r|}{ Variable name } & Modulus & amount & Statistic $\mathrm{T}$ & $\begin{array}{l}\text { meaningf } \\
\text { ul level }\end{array}$ \\
\hline \multicolumn{2}{|r|}{ fixed number } & $\beta_{0}$ & 0.811 & 2.847 & 0.014 \\
\hline OPNCHG & $\begin{array}{c}\text { Variations value of Auditing opinion } \\
\text { type }\end{array}$ & $\beta_{1}$ & 1.641 & 2.873 & 0.026 \\
\hline UE & $\begin{array}{c}\text { Changes percent in pure profit toward } \\
\text { past period }\end{array}$ & $\beta_{2}$ & 1.034 & 5.073 & 0.000 \\
\hline LEV & Financial fulcrum & $\beta_{3}$ & -1.098 & -3.809 & 0.0038 \\
\hline AS & Shift auditor & $\beta_{4}$ & -0.754 & -4.378 & 0.0021 \\
\hline DUAL & Manager dual & $\beta_{5}$ & -3.215 & -0.987 & 0.342 \\
\hline \multicolumn{2}{|r|}{ Determination modulus } & 0.568 & \multicolumn{2}{|c|}{ Statistic F } & 7.342 \\
\hline \multirow{2}{*}{\multicolumn{2}{|c|}{ Adapted determination modulus }} & \multirow{2}{*}{0.514} & \multirow{2}{*}{\multicolumn{2}{|c|}{$\begin{array}{l}\text { Meaningfully(p-value) } \\
\text { Durbin Watson statistic }\end{array}$}} & 0.000 \\
\hline & & & & & 1.742 \\
\hline
\end{tabular}

\section{Total conclusion:}

In analysis of upon conclusions we can say that auditing is as a superintendence mechanism that final product of the auditing report is considered relation to doubts and uncertainly on quality of reported accounting 
information, good auditing report makes to increase information credit and quality of financial information where as being on time is one of the most important property quality of information, therefore it is supposed to correlate directly that positive changes in auditor, opinion type and being on time financial reports.

As for positive relation to variation of Auditing opinion type with being on time accepted companies revelation in Tehran commercial paper bourse actives of fund Market, determiners, financial analyzer and defacto and potential investors in commercial paper bourse they can when analysis on investment schemes in financial finances and commercial paper, they decide optimumly and cause adventure minimum and the most revenue as for positive variation of Auditing opinion type that effect positively on being on time financial report and companies revelation.

\section{References}

Berger, P. \&Hann, R. (2007), 'Segment profitability and the proprietary and agency costs of disclosure'. The Accounting Review, Vol. 82, No. 4, pp. 869-906.

Beyer, A., Cohen, D., Lys, T. \& Walther, B. (2010).The financial reporting environment: review of the recent literature. Journal of Accounting and Economics, 50,2-3, 296343.

Pittman, J. and Fortin, S. (2004) Auditor choice and the cost of debt capital for newly public firms', Journal of Accounting and Economics, 37, 113-36.

Sands, J. and J. Mc Phail, Choice Criteria of Listed Australian Public Companies for Selecting an Auditor: An Explanatory Study, International Journal of Business Studies, Vol.11, No.1, 2003, pp.109-133

SDA Bocconi School of Management (2004), The impact of mandatory audit rotation on audit quality and on audit pricing: the case of Italy. Academic research Unpublished .

Sercu, P., Vander Bauwhede, H. \&Willekens, M.(2002), 'Earnings quality in privately held firms: The roles of audits, stakeholders and governance mechanisms', unpublished working paper, KULeuven.

Stefaniak,M,C.Robertson, C,J,Houston, W,R, The Causes and Consequences of Auditor Switching: A review of the Literature,Journal of Accounting Literature

Sundgren, S. \& Johansson, C. (2004), 'The effects of the auditor's professional qualification and the firm's financial health on depreciation in Finland', Accounting and Business Research, Vol. 34, No. 2, pp.125-43.

Etemadi, Hoseyn`Amirkhani, oorosh\& Rezaee, Mohabbat.(2011).The containing of value reveling compulsory: Evidences of accepted Companies in Tehran commercial paper bourse Journal of commercial paper bourse,No 13,235-252.

Valas, \&..... (2010), the rule of economic Auditing in free market and under control market Amir Aslani Translate, auditing organization publication, No 4 (2011).

Fakhari, Hoseyn\& Falah Mohammadi,Narges. (2009). The studing of effect information revealing on Stock Cashing of accepted Companies in Tehran commericial papar bourse. Researches Auditing, No 4.

Karami, Gh., Bazrafshan, A., (2009), the results of replace Auditor, Journal of Accountant, No 218، Pa 58- 63.

Mahdavi poor, Ali؟ Moosavi shiri, Mahmood\& Karimi Riabi, Alireza. (2010), the effect Elements on information revealing via accepted Companies in Tehran commercial paper bourse website, Accounting and Auditing Researches, No 5.

Hasas Yeganeh, Y., Pakizeh, K, (2007), finansial reporting Quality, Auditing and Sovereignty company, Journal of Accountant, No 182. 
commercial paper bourse organization (2007), direction of reliable Auditing institutions commercial paper bourse organization, Tehran.

commercial paper bourse organization (2007), the set of laws and rules Iran Capital Market, Tehran
Noravesh, Iraj \& Hoseyni, Seyad Ali, (2008)," The studding of relation between revealing quality (ability of reliance and be on time) and benefit Management, Journal of studies Accountant And Auditing, No 55. 